\title{
THE EFFECTS OF CASTRATION ON THE COMPOSITION OF RABBIT EPIDIDYMAL PLASMA
}

\author{
R. JONES* AND T. D. GLOVER \\ Unit of Reproductive Biology, University of Liverpool, \\ P.O. Box 147, Liverpool L69 3BX
}

(Received 24th fuly 1972)

Summary. The composition of luminal plasma from the cauda epididymidis of rabbits has been investigated after prolonged retention of spermatozoa in the cauda epididymidis of entire animals, and of castrated animals both with and without hormone replacement. The morphology of the contained spermatozoa and the epididymal cells has also been examined.

In the presence of androgen, spermatozoa survived for 4 to 5 weeks before degenerative changes became apparent and the composition of the epididymal plasma and the histological characteristics of the lining cells were not seriously affected during this period. The only change in the plasma which could be due to sperm death was an increase in the lactic dehydrogenase (LDH) activity. After androgen withdrawal, spermatozoa degenerated rapidly and there were considerable changes in the composition of the luminal plasma. There was a rapid increase in the level of sodium ions and $\mathrm{pH}$, and a decrease in the concentrations of glycerylphosphorylcholine (GPC) and protein. The activity of acid phosphatase and LDH also decreased. Initially, the concentration of inorganic phosphate and potassium increased but this was soon followed by a decrease. Five weeks after castration, all the spermatozoa disappeared from the epididymis and the epididymal cells had regressed. If testosterone replacement was given at this stage, the level of sodium ions in the plasma decreased and the concentration of GPG increased. The epididymal cells were also restored to their normal histological appearance.

These results provide evidence that, in the presence of androgen, the epididymal cells in the cauda epididymidis actively maintain a constant milieu in the lumen of the duct by their capacity for absorption and secretion. If androgen is withdrawn, these functions cease and considerable changes take place in the lumen.

\section{INTRODUCTION}

The prolonged viability of spermatozoa in the cauda epididymidis of mammals

* Present address: A.R.G. Unit of Reproductive Physiology and Biochemistry, 307 Huntingdon Road, Cambridge CB3 0JQ. 
has been well documented (Hammond \& Asdell, 1926; Snell, 1933; White, 1933; Paŭfler \& Foote, 1968; Tesh \& Glover, 1969). It is also known that the epididymal epithelium is dependent on circulating androgen (see Mann, 1964), and that if androgen is withdrawn by means of castration, then sperm survival in the cauda epididymidis is drastically curtailed (Mann, 1964; LubiczNawrocki \& Glover, 1970). However, there is no information in the literature on the chemical nature of the milieu of spermatozoa in the cauda epididymidis during their prolonged retention therein or after androgen withdrawal. It has been shown that the fluid or 'plasma' surrounding spermatozoa in the lumen of the cauda epididymidis is very different from that of other body fluids (Scott, Wales, Wallace \& White, 1963; Crabo \& Gustafsson, 1964; Mann, 1964; Crabo, 1965; Wales, Wallace \& White, 1966; Jones, 1973) and it may be that this is related to the prolonged survival of spermatozoa in this part of the duct.

In the present study, the composition of the luminal plasma from the cauda epididymidis of rabbits has been investigated under different hormonal conditions, and an attempt has been made to relate the composition of plasma to the morphology of epididymal spermatozoa and the function of the epididymal cells.

\section{MATERIALS AND METHODS}

A total of sixty-nine adult male rabbits of mixed strain was used in four experiments. Animals were caged individually and maintained on a diet of SGl pellets (Nutrients Ltd, Liverpool) and water. One week before surgery, all rabbits were allowed to ejaculate once and only those with good quality semen were used.

Twelve adult males were anaesthetized with an intravenous injection of sodium pentabarbitone (Nembutal, Abbott Laboratories) and were bilaterally castrated through a scrotal incision. Two ligatures, one on the distal part of the corpus epididymidis and another on the ductus deferens, were used to isolate the cauda epididymidis and to prevent the in- or outflow of spermatozoa. Care was taken to avoid undue disturbance to the blood supply when applying the ligatures. The epididymides were returned to the scrotum and the incisions were closed with interrupted nylon sutures and 'Octaflex' antiseptic plastic dressing (Ward Blenkinsop \& Co., London). Recovery was uneventful and these animals are referred to hereafter as the 'castrate group'.

A further eighteen rabbits were castrated and the epididymides were ligated in a similar fashion, but they were given a subcutaneous implant $(50 \mathrm{mg})$ of testosterone propionate (Organon Laboratories, London) at the time of castration. These animals constituted the 'hormone replacement group'. In an additional eighteen males, the 'ligated control group', the testes remained intact and the cauda epididymidis was isolated with ligatures.

In order to investigate the effects of testosterone replacement after a prolonged period of castration, twenty-one males were bilaterally castrated and only received an implant of testosterone propionate 5 weeks later. These males were referred to as the 'delayed replacement group'.

The contents of the cauda epididymidis were collected from three animals 
per week in each treatment group, using the cannulation procedure of Jones \& Glover (1973). The experiment was terminated after 8 weeks in the ligated control' and 'hormone replacement' groups, after 7 weeks in the 'delayed replacement group', and after 5 weeks in the 'castrate group'. The epididymal contents from each animal were treated separately, and after centrifugation at $12,000 \mathrm{~g}$ for $5 \mathrm{~min}$, the spermatocrit (packed cell volume) and 'volume of plasma collected' per rabbit were recorded. The plasma was stored under mineral oil at $-20^{\circ} \mathrm{C}$, and was then analysed for sodium and potassium ions, total protein, inorganic phosphate, glycerylphosphorylcholine (GPC), acid phosphatase, alkaline phosphatase, lactic dehydrogenase (LDH), $\alpha$-mannosidase, $\beta$ - $\mathcal{N}$-acetylglucosaminidase, osmotic pressure and $\mathrm{pH}$ (see Jones \& Glover, 1973).

Before centrifugation, samples of epididymal contents were mixed with a drop of aqueous nigrosin-eosin for 5 min (Campbell, Dott \& Glover, 1956) and smeared on clean glass slides. Percentages of stained ('dead') and decapitate spermatozoa were estimated from counts of 300 spermatozoa in duplicate smears.

The epididymides were removed after collection of the epididymal contents, fixed in Bouin's fluid, and processed by routine histological methods. Sections of the cauda epididymidis were cut at $6 \mu \mathrm{m}$, stained with Erlich's haematoxylin and eosin, and mounted with DPX mounting medium. Measurements of the diameter of the lumen and of the height of the epithelial cells were made with a micrometer eye-piece at magnifications of $\times 40$ and $\times 400$.

Peripheral blood was collected from the marginal ear vein and testosterone levels were estimated by means of radioimmunoassay.

All these results were assessed for significance using the Student $t$ test.

\section{RESULTS}

The results for the first three experiments are shown in Tables 1 to 4 . They show that after castration, spermatozoa in the cauda epididymidis died and disintegrated so that by the 5th week, they had disappeared completely and the spermatocrit was zero (Table 1 and see Pl. 1, Fig. 2). In the 'ligated control' and 'hormone replacement' groups, however, significant degeneration within the sperm population was not apparent until 3 to 5 weeks had elapsed. When hormone was present, the spermatozoa did not disappear and during this period, any decrease in spermatocrit could be adequately accounted for by an increase in the volume of plasma collected. There was, in fact, a significant negative correlation between the spermatocrit and the volume of plasma collected (castrate group, $r=0.862, P<0.01$; hormone replacement group, $r=0.613, P<0.01)$.

In the 'castrate group', an increase in the volume of plasma collected was accompanied by considerable changes in its composition. The most noticeable of these was a rapid increase in levels of sodium and potassium ions and inorganic phosphate, and a decrease in the concentrations of GPC and total protein and in the activity of acid phosphatase (Tables 2 and 3 ). It was noticeable that on the 1st week after castration, there was a transient increase in the 
Table 1. Morphological characteristics of spermatozoa, spermatocrit and volume of plasma collected from the cauda epididymidis of the rabbit

\begin{tabular}{|c|c|c|c|c|c|}
\hline $\begin{array}{c}\text { Experimental } \\
\text { group }\end{array}$ & $\begin{array}{c}\text { Weeks } \\
\text { after } \\
\text { operation }\end{array}$ & $\begin{array}{c}\% \\
\text { stained } \\
\text { spermatozoa }\end{array}$ & $\begin{array}{c}\% \\
\text { decapitate } \\
\text { spermatozoa }\end{array}$ & $\begin{array}{c}\% \\
\text { spermatocrit }\end{array}$ & $\begin{array}{l}\text { Volume of } \\
\text { plasma } \\
\text { collected } \\
\quad(\mu l)\end{array}$ \\
\hline Normal (intact) & & $7 \cdot 3 \pm 2 \cdot 7$ & $0.6 \pm 0.4$ & $20 \cdot 4 \pm 2 \cdot 0$ & $75 \cdot 2 \pm 28 \cdot 8$ \\
\hline $\begin{array}{l}\text { Ligated control } \\
\text { group }\end{array}$ & $\begin{array}{l}1 \\
2 \\
3 \\
5 \\
6 \\
8\end{array}$ & $\begin{array}{l}11 \cdot 7 \pm 2 \cdot 1 \\
12 \cdot 8 \pm 1.8 \\
13.9 \pm 0.9 \\
39.9 \pm 12 \cdot 8 \\
99.2 \pm 1.7 \\
96.3 \pm 1 \cdot 2\end{array}$ & $\begin{array}{r}3.5 \pm 1.2 \\
5 \cdot 1 \pm 0.7 \\
9 \cdot 7 \pm 4 \cdot 1 \\
16 \cdot 4 \pm 6.5 \\
65.8 \pm 6.2 \\
39.9 \pm 8.3\end{array}$ & $\begin{array}{r}21 \cdot 7 \pm 2 \cdot 1 \\
23 \cdot 4 \pm 3 \cdot 5 \\
24 \cdot 9 \pm 4 \cdot 5 \\
16 \cdot 1 \pm 3 \cdot 8 \\
13 \cdot 3 \pm 1 \cdot 2 \\
8 \cdot 5 \pm 1 \cdot 9\end{array}$ & $\begin{array}{l}112 \cdot 2 \pm 25 \cdot 4 \\
158 \cdot 7 \pm 44 \cdot 8 \\
221 \cdot 2 \pm 31 \cdot 5 \\
212 \cdot 8 \pm 22 \cdot 3 \\
368 \cdot 6 \pm 65 \cdot 1 \\
360 \cdot 1 \pm 71 \cdot 2\end{array}$ \\
\hline Castrated group & $\begin{array}{l}1 \\
2 \\
3 \\
5\end{array}$ & $\begin{array}{rr}22 \cdot 3 \pm & 2 \cdot 1 \\
* * 89 \cdot 0 \pm & 4 \cdot 7 \\
* * 100 \cdot 0 \pm & 0.0 \\
& \end{array}$ & $\begin{array}{r}4.3 \pm 2.1 \\
* * 28.7 \pm 3.7 \\
* * 79.5 \pm 6.4 \\
\end{array}$ & $\begin{array}{l}* 29.9 \pm 2.2 \\
20.3 \pm 0.8 \\
* * 5.6 \pm 1.3 \\
* * 0.0\end{array}$ & $\begin{array}{l}151 \cdot 4 \pm 21 \cdot 1 \\
223 \cdot 6 \pm 65 \cdot 4 \\
327 \cdot 5 \pm 84 \cdot 1 \\
365 \cdot 1 \pm 30 \cdot 5\end{array}$ \\
\hline $\begin{array}{l}\text { Hormone } \\
\text { replacement } \\
\text { group }\end{array}$ & $\begin{array}{l}1 \\
2 \\
3 \\
5 \\
6 \\
8\end{array}$ & $\begin{array}{r}9 \cdot 3 \pm 5 \cdot 2 \\
12 \cdot 8 \pm 3 \cdot 3 \\
17 \cdot 9 \pm 4 \cdot 8 \\
92 \cdot 8 \pm 2 \cdot 7 \\
96 \cdot 1 \pm 0 \cdot 3 \\
97 \cdot 8 \pm 9 \cdot 4\end{array}$ & $\begin{array}{r}2 \cdot 8 \pm 6 \cdot 4 \\
3 \cdot 9 \pm 2 \cdot 1 \\
6 \cdot 7 \pm 7 \cdot 3 \\
43 \cdot 1 \pm 19 \cdot 5 \\
57 \cdot 3 \pm 12 \cdot 1 \\
39 \cdot 6 \pm 10 \cdot 8\end{array}$ & $\begin{array}{r}29 \cdot 7 \pm 5 \cdot 9 \\
23 \cdot 7 \pm 5 \cdot 3 \\
14 \cdot 7 \pm 5 \cdot 3 \\
9 \cdot 7 \pm 2 \cdot 1 \\
11 \cdot 6 \pm 1 \cdot 3 \\
5 \cdot 8 \pm 0 \cdot 9\end{array}$ & $\begin{array}{r}87 \cdot 2 \pm 19 \cdot 1 \\
142 \cdot 0 \pm 48 \cdot 3 \\
222 \cdot 7 \pm 51 \cdot 9 \\
290 \cdot 6 \pm 64 \cdot 7 \\
328 \cdot 1 \pm 29 \cdot 1 \\
335 \cdot 0 \pm 28 \cdot 3\end{array}$ \\
\hline
\end{tabular}

Values for normal animals are taken from Jones \& Glover (1973). Each value is the mean \pm S.E. for three animals.

* Significantly different from ligated controls $(P<0 \cdot 05)$.

** Significantly different from ligated controls $(P<0.01)$.

Table 2. Chemical composition of epididymal plasma from the cauda epididymidis of the rabbit

\begin{tabular}{|c|c|c|c|c|c|}
\hline $\begin{array}{c}\text { Experimental } \\
\text { group }\end{array}$ & $\begin{array}{c}\text { Weeks } \\
\text { after } \\
\text { operation }\end{array}$ & $\begin{array}{c}\mathrm{Na}^{+} \\
\text {(mequiv.|litre) }\end{array}$ & $\begin{array}{c}\kappa^{+} \\
\text {(mequiv./litre) }\end{array}$ & $\begin{array}{c}G P C \\
(m g / 100 m l)\end{array}$ & $\begin{array}{c}\text { Inorganic } \\
\text { phosphate } \\
(m g P / 100 m l)\end{array}$ \\
\hline Normal (intact) & & $20 \cdot 7 \pm 2 \cdot 3$ & $24 \cdot 8 \pm 1 \cdot 2$ & $766 \cdot 6 \pm 41 \cdot 6$ & $12 \cdot 42 \pm 1 \cdot 0$ \\
\hline $\begin{array}{l}\text { Ligated control } \\
\text { group }\end{array}$ & $\begin{array}{l}1 \\
2 \\
3 \\
5 \\
6 \\
8\end{array}$ & 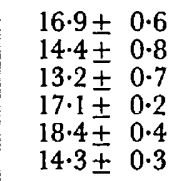 & $\begin{array}{ll}20 \cdot 4 \pm & 0.8 \\
19 \cdot 9 \pm & 1 \cdot 2 \\
15 \cdot 4 \pm & 1 \cdot 0 \\
20 \cdot 1 \pm & 9 \cdot 1 \\
16 \cdot 9 \pm & 2 \cdot 7 \\
16 \cdot 4 \pm & 3 \cdot 4\end{array}$ & $\begin{array}{l}614 \cdot 0 \pm 30 \cdot 2 \\
687 \cdot 3 \pm 24 \cdot 2 \\
670 \cdot 6 \pm 16 \cdot 5 \\
705 \cdot 3 \pm 35 \cdot 6 \\
729 \cdot 6 \pm 16 \cdot 4 \\
694 \cdot 1 \pm 98 \cdot 1\end{array}$ & $\begin{array}{l}14 \cdot 2 \pm 1 \cdot 3 \\
16 \cdot 7 \pm 1 \cdot 1 \\
20 \cdot 3 \pm 1 \cdot 2 \\
22 \cdot 6 \pm 2 \cdot 9 \\
28 \cdot 5 \pm 4 \cdot 1 \\
22 \cdot 6 \pm 2 \cdot 3\end{array}$ \\
\hline Castrated group & $\begin{array}{l}1 \\
2 \\
3 \\
5\end{array}$ & $\begin{array}{r}27.6 \pm 4.8 \\
* * 54.6 \pm 4.2 \\
* * 80.5 \pm 30.3 \\
* * 86.5 \pm 8.4\end{array}$ & $\begin{array}{r}25 \cdot 2 \pm 3 \cdot 1 \\
* * 35 \cdot 9 \pm 2.4 \\
* 47 \cdot 9 \pm 11 \cdot 0 \\
22.9 \pm 5 \cdot 7\end{array}$ & $\begin{array}{r}* * 1155 \cdot 9 \pm 67.9 \\
815 \cdot 2 \pm 60 \cdot 4 \\
308 \cdot 4 \pm 105 \cdot 0 \\
* * 18.2 \pm \quad 8 \cdot 4\end{array}$ & $\begin{array}{r}* 33.2 \pm 2.1 \\
* * 53.9 \pm 3.2 \\
14.1 \pm 1.7 \\
* * 3.2 \pm 0.4\end{array}$ \\
\hline $\begin{array}{l}\text { Hormone } \\
\text { replacement } \\
\text { group }\end{array}$ & $\begin{array}{l}1 \\
2 \\
3 \\
5 \\
6 \\
8\end{array}$ & $\begin{array}{ll}17 \cdot 5 \pm & 0.3 \\
14 \cdot 1 \pm & 0.6 \\
11 \cdot 3 \pm & 1 \cdot 1 \\
14.5 \pm & 1 \cdot 2 \\
13 \cdot 6 \pm & 0 \cdot 8 \\
12 \cdot 8 \pm & 0 \cdot 4\end{array}$ & $\begin{array}{ll}22 \cdot 4 \pm & 1 \cdot 3 \\
20 \cdot 3 \pm & 1 \cdot 1 \\
24 \cdot 6 \pm & 0 \cdot 4 \\
17 \cdot 2 \pm & 0 \cdot 7 \\
16 \cdot 5 \pm & 1 \cdot 8 \\
18 \cdot 2 \pm & 1 \cdot 4\end{array}$ & $\begin{array}{l}706 \cdot 1 \pm 29 \cdot 0 \\
791 \cdot 4 \pm 27 \cdot 3 \\
815 \cdot 4 \pm 98 \cdot 4 \\
774 \cdot 6 \pm 8 \cdot 3 \\
574 \cdot 1 \pm 31 \cdot 7 \\
830 \cdot 4 \pm 35 \cdot 4\end{array}$ & $\begin{array}{l}12 \cdot 7 \pm 0.4 \\
15 \cdot 8 \pm 0 \cdot 9 \\
20 \cdot 2 \pm 2 \cdot 3 \\
24 \cdot 7 \pm 2 \cdot 3 \\
27 \cdot 8 \pm 3 \cdot 1 \\
26 \cdot 6 \pm 1 \cdot 3\end{array}$ \\
\hline
\end{tabular}

Each value is the mean \pm S.E. for three animals.

* Significantly different from ligated controls, $P<0.05$.

** Significantly different from ligated controls, $P<0.01$. 
Table 3. Chemical composition of epididymal plasma from the cauda epididymidis of the rabbit

\begin{tabular}{|c|c|c|c|c|c|}
\hline $\begin{array}{l}\text { Experimental } \\
\text { group }\end{array}$ & $\begin{array}{c}\text { Weeks } \\
\text { after } \\
\text { operation }\end{array}$ & $\begin{array}{c}\text { Total } \\
\text { protein } \\
(\mathrm{g} / 100 \mathrm{ml})\end{array}$ & $\begin{array}{l}\text { Osmotic } \\
\text { pressure } \\
\left(\Delta T_{\mathrm{f}}{ }^{\circ} \mathrm{C}\right)\end{array}$ & $\begin{array}{c}\text { Acid } \\
\text { phosphatase } \\
(\text { i.u. })\end{array}$ & $\begin{array}{l}L D H \\
(\text { i.u. })\end{array}$ \\
\hline Normal (intact) & & $4 \cdot 03 \pm 0 \cdot 23$ & $0.580 \pm 0.035$ & $106 \pm 41 \cdot 3$ & $648 \pm 91$ \\
\hline $\begin{array}{l}\text { Ligated control } \\
\text { group }\end{array}$ & $\begin{array}{l}1 \\
2 \\
3 \\
5 \\
6 \\
8\end{array}$ & $\begin{array}{l}4 \cdot 80 \pm 0 \cdot 59 \\
5 \cdot 18 \pm 0 \cdot 33 \\
4 \cdot 83 \pm 0 \cdot 26 \\
6 \cdot 35 \pm 0 \cdot 26 \\
6 \cdot 35 \pm 1 \cdot 15 \\
6 \cdot 23 \pm 1 \cdot 17\end{array}$ & $\begin{array}{l}0.604 \pm 0.015 \\
0.580 \pm 0.021 \\
0.554 \pm 0.028 \\
0.704 \pm 0.021 \\
0.714 \pm 0.110 \\
0.616 \pm 0.013\end{array}$ & $\begin{array}{l}239 \pm 11.4 \\
357 \pm 46.7 \\
402 \pm 100.9 \\
336 \pm 11.4 \\
452 \pm 32.8 \\
433 \pm 210.1\end{array}$ & $\begin{array}{r}718 \pm 134 \\
2200 \pm 546 \\
3442 \pm 1121 \\
5835 \pm 3421 \\
11,565 \pm 1340 \\
6974 \pm 2078\end{array}$ \\
\hline Castrated group & $\begin{array}{l}1 \\
2 \\
3 \\
5\end{array}$ & $\begin{array}{r}6.89 \pm 1.17 \\
6.23 \pm 1.41 \\
3.21 \pm 1.36 \\
* * 0.64 \pm 0.26\end{array}$ & $\begin{array}{l}0.582 \pm 0.071 \\
0.617 \pm 0.094 \\
0.426 \pm 0.036 \\
0.590 \pm 9 \cdot 101\end{array}$ & $\begin{array}{cc}250 & \pm 810 \\
261 & \pm 21 \cdot 4 \\
201 & \pm 64 \cdot 2 \\
* * 27 \cdot 6 \pm & 10 \cdot 3\end{array}$ & $\begin{array}{r}2727 \pm 584 \\
721 \pm 210 \\
2104 \pm 1111 \\
* * 456 \pm 104\end{array}$ \\
\hline $\begin{array}{l}\text { Hormone } \\
\text { replacement } \\
\text { group }\end{array}$ & $\begin{array}{l}1 \\
2 \\
3 \\
5 \\
6 \\
8\end{array}$ & $\begin{array}{l}5 \cdot 17 \pm 0.64 \\
5.68 \pm 0.71 \\
5.54 \pm 0.68 \\
6.4 \pm 0.35 \\
6.08 \pm 0.33 \\
6 \cdot 13 \pm 1.08\end{array}$ & $\begin{array}{l}0.545 \pm 0.019 \\
0.621 \pm 0.028 \\
0.707 \pm 0.036 \\
0.614 \pm 0.041 \\
0.689 \pm 0.040 \\
0.710 \pm 0.060\end{array}$ & 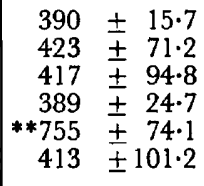 & $\begin{array}{l}2653 \pm 103 \\
1271 \pm 234 \\
2480 \pm 1225 \\
1515 \pm 138 \\
6916 \pm 2890 \\
2827 \pm 1009\end{array}$ \\
\hline
\end{tabular}

Each value is the mean \pm S.E. for three animals. i.u. = International Units ( $\mu$ mol substrate hydrolysed/min/litre of plasma at $37^{\circ} \mathrm{C}$ ).

** Significantly different from ligated controls, $P<0.01$.

concentrations of GPC and protein and also in the spermatocrit reading, but this was reversed by the 5 th week when low readings were obtained in each case. The activity of $\mathrm{LDH}$ also decreased to low levels after 5 weeks.

In the 'ligated control' and 'hormone replacement' groups, the composition of the epididymal plasma did not alter drastically from that in normal (unligated) animals (see Jones \& Glover, 1973). The levels of sodium, potassium

Table 4. Mean lumen diameter and epithelial cell height of the cauda epididymidis of the rabbit during castration for 5 weeks followed by hormone replacement

\begin{tabular}{|c|c|c|}
\hline Weeks after castration & $\begin{array}{c}\text { Lumen } \\
\text { diameter }(\mu m)\end{array}$ & $\begin{array}{l}\text { Epithelial cell } \\
\text { height }(\mu m)\end{array}$ \\
\hline $\begin{array}{c}\text { Normal animal } \\
1 \\
2 \\
3 \\
5\end{array}$ & $\begin{array}{l}654 \cdot 0 \pm 26 \cdot 4 \\
609 \cdot 7 \pm 33 \cdot 8 \\
574 \cdot 1 \pm 41 \cdot 7 \\
398 \cdot 9 \pm 29 \cdot 2 \\
374 \cdot 4 \pm 54 \cdot 9\end{array}$ & $\begin{array}{r}16 \cdot 2 \pm 0 \cdot 8 \\
16 \cdot 0 \pm 0 \cdot 9 \\
10 \cdot 8 \pm 0 \cdot 6 \\
6 \cdot 1 \pm 0 \cdot 4 \\
5 \cdot 1 \pm 0 \cdot 1\end{array}$ \\
\hline $\begin{array}{c}\text { Testosterone implant } \\
6 \\
7 \\
8 \\
9 \\
10 \\
11 \\
12\end{array}$ & $\begin{array}{r}90 \cdot 3 \pm 9 \cdot 8 \\
364 \cdot 7 \pm 18 \cdot 9 \\
358 \cdot 1 \pm 36 \cdot 7 \\
360 \cdot 5 \pm 18 \cdot 7 \\
422 \cdot 4 \pm 21 \cdot 7 \\
418 \cdot 7 \pm 31 \cdot 7 \\
454 \cdot 9 \pm 33 \cdot 2\end{array}$ & $\begin{array}{l}25 \cdot 8 \pm 1 \cdot 2 \\
14 \cdot 8 \pm 0 \cdot 9 \\
16 \cdot 9 \pm 1 \cdot 7 \\
16 \cdot 3 \pm 1 \cdot 0 \\
19 \cdot 5 \pm 1 \cdot 5 \\
20 \cdot 8 \pm 2 \cdot 7 \\
15 \cdot 7 \pm 0 \cdot 9\end{array}$ \\
\hline
\end{tabular}

Values are the mean \pm S.E. for three animals. Measurements were made on seven tubules per section for five sections of the cauda epididymidis of each animal. 
and GPC remained within normal limits also, although there was a slight increase in the concentrations of protein and inorganic phosphate, and in acid phosphatase activity. The only change was an increase in the level of LDH activity during the 5 th and 6 th weeks, to be followed by a decrease during the 8 th week (Table 3 ). This was in distinct contrast to the situation after castration.

Of the other enzymes studied, namely alkaline phosphatase, $\beta$ - $\mathcal{N}$-acetylglucosaminidase and $\alpha$-mannosidase, there was a similar pattern of change to

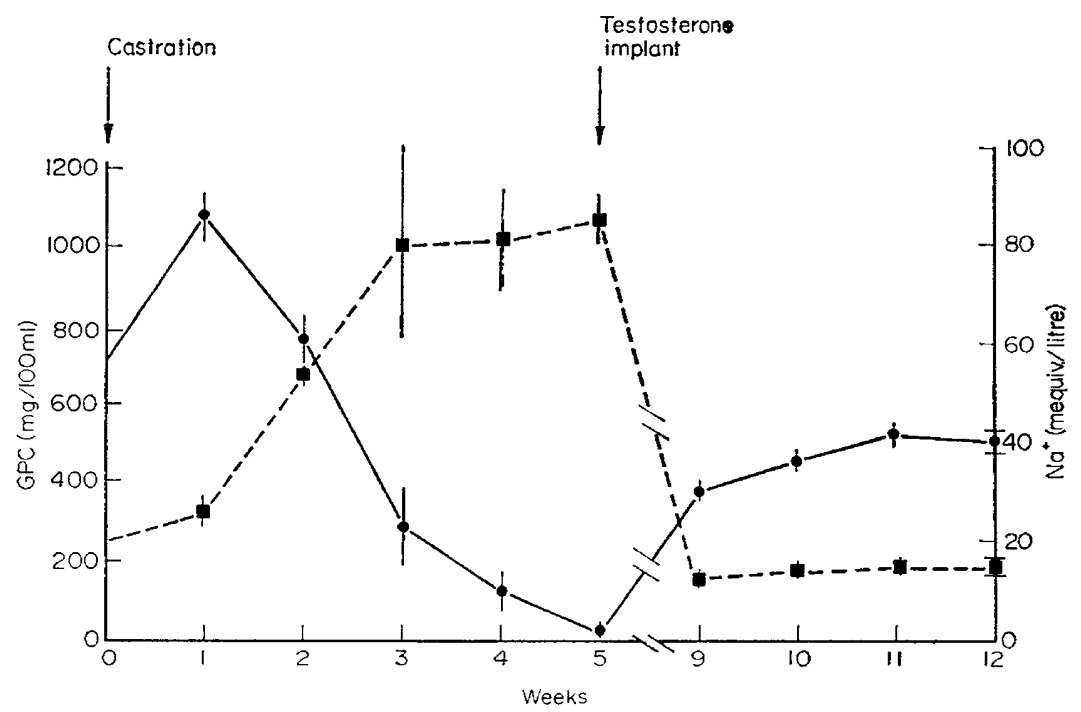

Texr-FIG. 1. The concentrations of GPG ( $)$ and $\mathrm{Na}^{+}$ions $(\mathbf{a})$ in rabbit epididymal plasma after castration and after castration followed by a testosterone implant on the 5 th week (see text). Each value is the mean \pm S.E. for three animals.

that observed for acid phosphatase so that after 5 weeks of castration, their activity in the plasma had decreased to less than $20 \%$ of that in the 'ligated controls'.

The osmotic pressure measurements (Table 3) deserve further mention, however, since after castration, the osmotic pressure of the epididymal plasma was not significantly less than that in the plasma of ligated controls where it always remained hypertonic to blood (blood plasma, $\Delta \mathrm{T}_{\mathrm{f}}=0.572^{\circ} \mathrm{C}$ ). By

\section{EXPLANATION OF PLATE 1}

Fig. 1. Histological section of the cauda epididymidis of a control rabbit 5 weeks after ligation (see text). The lumen is packed with spermatozoa. Haematoxylin and eosin. $\times 70$.

Fig. 2. Histological section of the cauda epididymidis of a rabbit 5 weeks after castration (see text). Note the wide lumen, absence of spermatozoa, and the total regression of the epididymal epithelium. Haematoxylin and eosin. $\times 70$.

Fig. 3. Histological section of the cauda epididymidis of a rabbit 5 weeks after castration and 1 week after being given a testosterone implant. Note the small lumen diameter. Folds in the epithelium appear as 'crypts' (arrowed). Haematoxylin and eosin. $\times 70$.

Fig. 4. Same as Fig. 3, but 5 weeks after receiving the testosterone implant. Note the reappearance of the wide lumen and the restoration of the epididymal epithelium (see Table 4). Haematoxylin and eosin. $\times 70$. 
PLATE

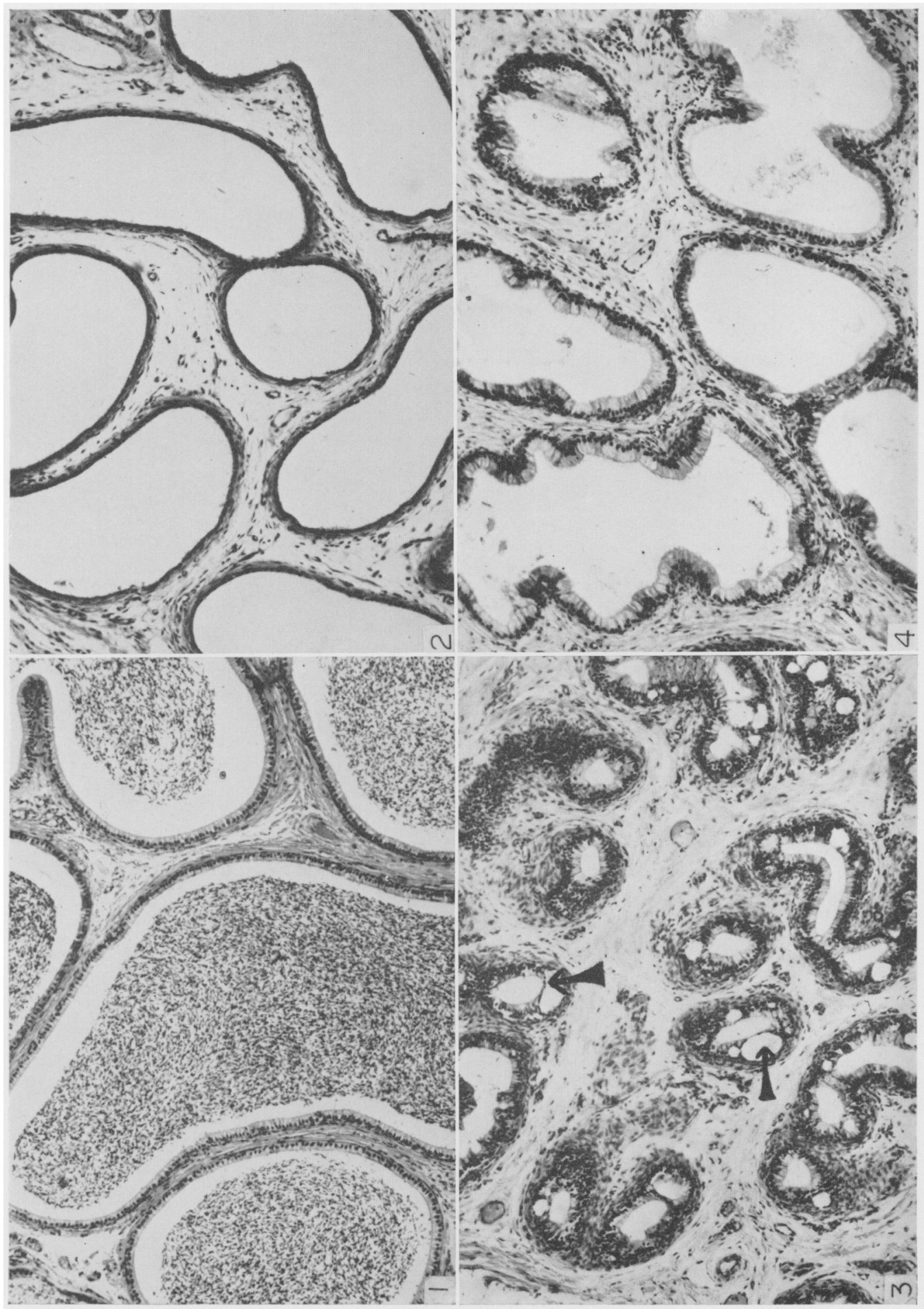

(Facing p. 410) 
contrast, the $\mathrm{pH}$ of the plasma increased rapidly after castration and reached mean values on the 1 st, 2 nd, $3 \mathrm{rd}$ and 5 th weeks of $6 \cdot 8,7 \cdot 2,7 \cdot 7$ and $8 \cdot 05$, respectively. In the 'ligated control' and 'hormone replacement' groups, the $\mathrm{pH}$ of the plasma remained below $7 \cdot 0$ for the duration of the experiment.

After castration, the epididymal epithelium began to regress and by the 5 th week, the cell height was greatly reduced and the stereocilia had disappeared completely (see Table 4 and Pl. 1, Fig. 2). The flattened appearance of the epithelium in these circumstances was due to the accumulation of 'fluid' (see earlier) which was prevented from leaving the epididymis by the ligature on the ductus deferens. If this ligature was omitted, the contents passed freely into the urethra and, in castrated animals, the cauda epididymidis was completely empty by the 4th week. In the 'ligated control' and 'hormone replacement' groups, the epididymal epithelium retained its normal histological appearance.

The results of delaying hormone replacement until 5 weeks after castration are shown in Text-fig. 1 and Pl. 1, Figs 3 and 4. One week after giving the testosterone implant, it was impossible to collect any 'fluid' from the epididymis. The lumen of the tubules had collapsed completely (see Table 4 and Pl. 1, Fig. 3) and it was not until the 4th week that small volumes could be collected again. The diameter of the lumen gradually increased during this time as did the epithelial cell height (Table 4 and Pl. 1, Fig. 4). At these times, when spermfree 'plasma' could be collected, it was found that the levels of sodium ions had declined to below normal levels while the concentration of GPC had increased (Text-fig. 1). The GPC concentration, however, never reached normal levels even after 7 weeks of hormone replacement when the $\mathrm{pH}$ of the plasma had also returned to values below $7 \cdot 0$.

These findings are of added interest when related to the levels of testosterone in the blood. Only two animals were used in this context but it was found that there was a rapid decrease in blood testosterone from over $500 \mathrm{ng} / 100 \mathrm{ml} 30$ min before castration, to less than $50 \mathrm{ng} / 100 \mathrm{ml} 2 \mathrm{hr}$ after castration. Twentyfour hours later, the testosterone concentration had fallen to less than $10 \mathrm{ng} / 100$ $\mathrm{ml}$. Within 3 days of giving an implant of testosterone propionate to 35-day castrates, however, the concentration of circulating testosterone increased to over $300 \mathrm{ng} / 100 \mathrm{ml}$.

\section{DISCUSSION}

This work has shown that the chemical composition of epididymal plasma in the cauda epididymidis is profoundly influenced by circulating androgen.

Isolation of this region by means of ligatures must, in part, create unphysiological conditions but disturbance of the blood supply is not apparent and although the lymphatics might be affected, the composition of the plasma does not appear to alter significantly (see Jones \& Glover, 1973). The use of ligatures can be justified on the grounds that any changes in the plasma must be due to altered function in the cauda epididymidis itself, and not to changes in higher regions of the duct.

Nevertheless, it is reasonable to assume that the composition of the plasma is 
the result of two interacting sources, the spermatozoa and the epididymal cells. If this is true, the situation might be represented as:

$$
\text { spermatozoa } \leftrightharpoons \text { epididymal plasma } \leftrightharpoons \text { epididymis }
$$

Changes in the composition of the plasma are thus fairly difficult to interpret, especially if both spermatozoa and epididymal cells are adversely affected. After castration, for example, rapid degeneration of spermatozoa coincides with the regression of epididymal cells. A corresponding increase in the levels of sodium and potassium ions and in the $\mathrm{pH}$ of the plasma strongly suggests a reduced absorptive capacity by the epididymis, although degenerating spermatozoa represent another potential source of inorganic ions (Quinn, White \& Wirrick, 1966). Similarly, it is difficult to be certain of the origin of high levels of inorganic phosphate 2 weeks after castration. Spermatozoa contain endogenous reserves of phospholipids (Hartree \& Mann, 1959, 1961) and nucleotides (Newton \& Rothschild, 1961; Brooks, 1970) and it is conceivable that after castration, there is a breakdown of these reserves with a release of free phosphate into the lumen. It is also possible that phosphorus-containing compounds in the plasma itself may be degraded, especially in view of the high levels of phosphatases in the plasma at this time. A third possibility is the direct release of phosphate from the epididymal cells into the lumen. Whatever the origin of phosphate, its interrelationships in the epididymis warrant further investigation.

The only parameter which is not significantly affected by castration is the osmotic pressure. This is maintained within normal levels in spite of a considerable increase in the ionic content of the plasma. A decrease in the concentration of other osmotically active substances in the plasma, therefore, seems likely.

In contrast to the above substances, a decreased concentration of GPC after castration can only be attributed to a reduction in the secretory activity of the epididymal cells. It is well known that GPC is actively synthesized by the epididymis (Dawson, Mann \& White, 1957; Scott et al., 1963; Mann, 1964; Wallace, Wales \& White, 1966) and that it is not metabolized directly by spermatozoa (White, Wallace, Wales \& Scott, 1961). Its occurrence in the epididymis is dependent on the presence of circulating androgen (Dawson \& Rowlands, 1959). Thus, in the 'ligated control' and 'hormone replacement' groups, normal secretory activity by the cells of the epididymis would seem to be retained, since the concentration of GPG in the plasma was within normal limits. These concentrations were maintained throughout the experimental periods in spite of spermatozoa degenerating and probably releasing intracellular constituents into the plasma after 4 or 5 weeks. An increase in the level of LDH activity in the plasma indicates that leakage of sperm contents occurred about this time (see Jones \& Glover, 1973). If other intracellular constituents such as potassium ions were released, however, their concentration never reached detectable proportions. Even LDH levels declined after about 8 weeks.

It seems, therefore, that in the presence of circulating androgen, the epithelial cells lining the cauda epididymidis serve to maintain a relatively stable luminal environment by virtue of their capacity for absorption and secretion. Further evidence of a potentiality for active secretion is provided by a progressive 
increase in the volume of the luminal fluid following isolation of the cauda epididymidis and, since the normal composition of the plasma was maintained over a period of 8 weeks, the increase would not seem to be due to the passive entry of fluid into the lumen. This does not apply to castrated animals, however, in which there is considerable change in the composition of the plasma and where secretion is probably inhibited.

The secretory and absorptive activity of the cells lining the cauda epididymidis seem to differ in their sensitivity to androgen. During the 1st week of castration, secretion appears to be halted but absorption seems to proceed. This should have a concentrating effect and, indeed, the spermatocrit and the concentrations of GPC and protein in the plasma increase during this time. The situation is only rectified later when absorptive activity is, presumably, also adversely affected by the lack of androgen. After a prolonged period of castration followed by testosterone replacement, absorptive activity is restored first so that superfluous fluid is quickly removed and renewed secretion only begins afterwards. This restoration of normal function is characterized by a decrease in the level of sodium ions and an increase in GPG. The GPC never quite reaches normal levels, however, which indicates that normally a proportion of the GPG in the lumen of the cauda epididymidis originates from higher up the duct, bearing in mind that in these experiments the cauda epididymidis was isolated by ligation. It may, of course, also reflect the lower potential of cells in this area for synthesizing GPG (Scott et al., 1963; Wallace et al., 1966).

Overall, therefore, the evidence presented here strongly suggests that in the presence of circulating androgen, the cells lining the cauda epididymidis actively maintain a stable milieu in the lumen of the duct. Any disturbance of this milieu, such as might result from the degeneration of some of the spermatozoa, seems to be compensated for by the normal secretory and absorptive activity of the epithelium. An important next step would be to determine the exact nature of the secretory and absorptive activity of the epididymal cells and the precise contribution of degenerating spermatozoa to the plasma following castration.

\section{AGKNOWLEDGMENTS}

The authors are indebted to the Ford Foundation for financial support, and to the Northern Ireland Ministry of Education for a grant to one of us (R.J.). We are grateful to $\mathrm{Mr} \mathrm{P}$. Rowe and Mr M. J. Stevenson for carrying out the testosterone assays, and to Mrs G. P. Boyd for technical assistance. We wish to thank also Miss C. Griffiths and Mr W. Davies for care of the animals, and Mrs J. Kelly for typing the manuscript.

\section{REFERENGES}

BRooks, D. E. (1970) Observations on the content of ATP and ADP in bull spermatozoa using the firefly luciferase system. F. Reprod. Fert. 23, 525.

Gampbell, R. C., Dott, H. M. \& Glover, T. D. (1956) Nigrosin eosin as a stain for differentiating live and dead spermatozoa. J. agric. Sci., Camb. 48, 1.

Grabo, B. (1965) Studies on the composition of epididymal content in bulls and boars. Acta vet. scand. 6, Suppl. 5. 
Crabo, B. \& Gustafsson, B. (1964) Distribution of sodium and potassium and its relation to sperm concentration in the epididymal plasma of the bull. F. Reprod. Fert. 7, 337.

Dawson, R. M. G., MANN, T. \& WhITE, I. G. (1957) Glycerylphosphorylcholine and phosphorylcholine in semen and their relationship to choline. Biochem. F. 65, 627.

Dawson, R. M. C. \& RowLANDs, I. W. (1959) Glycerylphosphorylcholine in the male reproductive organs of rats and guinea-pigs. Q. Jl exp. Physiol. 44, 26.

Hammond, J. \& Asdell, S. A. (1926) The vitality of the spermatozoa in the male and female tracts. Br. F. exp. Biol. 4, 155.

Hartree, E. F. \& Mann, T. (1959) Plasmalogen in ram semen and its role in sperm metabolism. Biochem. F. 71, 423.

Hartree, E. F. \& Mann, T. (1961) Phospholipids in ram semen; metabolism of plasmalogen and fatty acids. Biochem. 7. 80, 464.

Jones, R. (1973) Studies on the composition of epididymal plasma. Ph.D. thesis, University of Liverpool.

Jones, R. \& Glover, T. D. (1973) The collection and composition of epididymal plasma from the cauda epididymidis of the rabbit. F. Reprod. Fert. 34, 395.

Lubicz-Nawrocki, C. M. \& Glover, T. D. (1970) Effects of gonadectomy and testosterone replacement on the viability of epididymal spermatozoa in the golden hamster (Mesocricetus auratus). 7. Endocr. 48, xxii.

Mann, T. (1964) The biochemistry of semen and of the male reproductive tract. Methuen, London.

Newton, A. A. \& RothschiLd, LoRD (1961) Energy-rich phosphate compounds in bull semen: comparison of metabolism with anaerobic heat production and impedance change frequency. Proc. R. Soc. B, 155, 183.

PAứfler, S. K. \& Foote, R. H. (1968) Morphology, motility and fertility of spermatozoa recovered from different areas of ligated rabbit epididymides. F. Reprod. Fert. 17, 125.

Quinn, P. J., White, I. G. \& WirRick, B. R. (1966) The effect of dilution on the concentration of sodium, potassium, calcium and magnesium in ram and bull spermatozoa. F. Reprod. Fert. 12, 131 .

Scott, T. W., Wales, R. G., Wallace, J. C. \& White, I. G. (1963) Composition of ram epididymal and testicular fluid and biosynthesis of glycerylphosphorylcholine by the rabbit epididymis. 7. Reprod. Fert. 6, 49.

SNELL, G. D. (1933) X-ray sterility in the male house mouse. F. exp. Zool. 65, 421.

TESH, J. M. \& Glover, T. D. (1969) Ageing of spermatozoa in the male tract and its effect on fertility. 7. Reprod. Fert. 20, 287.

Wales, R. G., Wallace, J. C. \& White, I. G. (1966) Composition of bull epididymal and testicular fluid. F. Reprod. Fert. 12, 139.

Wallace, J. C., Wales, R. G. \& White, I. G. (1966) The respiration of the rabbit epididymis and its synthesis of GPC. Aust. F. biol. Sci. 19, 849.

White, W. E. (1933) The duration of fertility and the histological changes in the reproductive organs after ligation of the vasa efferentia in the rat. Proc. $R$. Soc. B, 113, 544.

White, I. G., Wallace, J. C., Wales, R. G. \& Scott, T. W. (1961) The occurrence and metabolism of glycerylphosphorylcholine in semen and the genital tract. In: Proc. 4th Int. Congr. Anim. Reprod., The Hague, p. 266. Drukkerij Trio, The Hague. 